\title{
IS VOLUNTARY ADMINISTRATION FAILING COMPANIES? AN \\ INVESTIGATION INTO THE OPERATION OF VOLUNTARY ADMINISTRATION IN NEW ZEALAND FROM INCEPTION TO 2019
}

\author{
Sebastian Ellice*
}

This article investigates the operation of voluntary administration in New Zealand from inception in 2007 to 2019. Voluntary administration is a formal insolvency procedure that is intended to maximise an insolvent company's chances of rehabilitation. Research undertaken for this article suggests that voluntary administration is not operating as was intended. It appears to have been underused and largely ineffective as a business rehabilitation mechanism. This article suggests that contributing reasons for the findings of the research include cost barriers for small businesses, a lack of confidence on behalf of creditors, and a misuse of voluntary administration by company directors. It proposes that useful reforms would be to reduce cost barriers and place limitations on when and how the procedure can be used.

\section{INTRODUCTION}

Voluntary administration (VA) was introduced in New Zealand in 2007, accompanied with high hopes for its success as a business rehabilitation scheme. Now, over 12 years later, it appears VA may have missed its mark. VA seems to have been underused and largely ineffective in successfully rehabilitating businesses. The aim of this article is to establish how VA has operated in practice over the last 12 years, to assess whether the aims of the government in introducing the regime have been met and, finally, to make suggestions for how the regime may be improved.

* Submitted for the LLB (Honours) Degree 2020 at Victoria University of Wellington. I would like to express my thanks to all who helped in the development of this article, in particular, my supervisor Victoria Stace, for her ongoing guidance and support. 


\section{SETTING THE SCENE}

\section{A What is Voluntary Administration?}

Voluntary administration is a formal insolvency procedure available to companies in New Zealand. The objectives of VA, set out in pt 15A of the Companies Act 1993, are to facilitate the administration of the business, property and affairs of an insolvent company, or a company that may become insolvent in the future, in a way that maximises the chances of the company continuing to exist. ${ }^{1}$ If this is not possible, VA should result in a better return for the company's creditors and shareholders than would result from immediate liquidation. ${ }^{2}$

The procedure for VA can be divided into three phases: the "initiating" phase, the "decision" phase and the "transition" phase. ${ }^{3}$ The "initiating phase" commences with the appointment of an administrator. ${ }^{4}$ An administrator can be appointed by either: ${ }^{5}$

(a) the company;

(b) a liquidator of the company;

(c) a secured creditor (with a charge over the whole, or substantially the whole, of the company's property); or

(d) the court (on the application of certain persons).

The party appointing the administrator (with the exception of secured creditors) must also hold the view that the company is insolvent or may become insolvent. ${ }^{6}$

Once appointed, the administrator assumes control over the company's affairs, ${ }^{7}$ and the company's directors cannot perform their functions or powers without prior written approval from the administrator (or unless expressly permitted by pt $15 \mathrm{~A}$ ). ${ }^{8}$ During the initiating phase, the administrator must call the first creditors' meeting to consider whether to appoint a committee of creditors and whether to replace the administrator. ${ }^{9}$

1 Section 239A(a).

2 Section 239A(b).

3 Paul Heath and Michael Whale (eds) Heath and Whale on Insolvency (online ed, LexisNexis) at [17.6].

4 At [17.6].

5 Companies Act, ss 239I-239L.

6 Sections 239I, 239J and 239L.

7 Section $239 \mathrm{U}$.

8 Section 239X.

9 Section 239AN. 
A key feature of VA is the moratorium period. Once an administrator is appointed, ${ }^{10}$ unsecured and secured creditors cannot enforce a charge over company property, ${ }^{11}$ and the owner or lessor of property that is in the company's possession cannot recover such property. ${ }^{12}$ In addition, proceedings may not be initiated or continued against the company without the administrator's written consent or the court's permission. ${ }^{13}$ However, creditors with a charge over the whole, or substantially the whole, of the company's property (called a "fully secured creditor" in this article), are not barred from enforcing a charge, provided they do so within 10 working days ${ }^{14}$ of the company entering VA. ${ }^{15}$ The moratorium lasts for the duration of the administration, ${ }^{16}$ giving the company some "breathing space" to regroup and assess the best way forward. ${ }^{17}$

The "decision" phase involves the administrator investigating the affairs of the company and preparing a report to present to creditors at the second meeting called the "watershed meeting". This meeting must be convened within 25 working days of the administrator being appointed (unless an extension is granted by the court). ${ }^{18}$ At the watershed meeting, creditors decide the future of the company by choosing one of three options: ${ }^{19}$

(a) execute a Deed of Company Arrangement (DOCA);

(b) return the company to its directors; or

(c) appoint a liquidator.

A DOCA is a binding arrangement between a company and its creditors that governs how the company's affairs will be dealt with once the administration ends. ${ }^{20}$ DOCAs are flexible, the terms

10 Section 239D

11 Section 239ABC; but see s 239ABL

12 Section 239ABD.

13 Section 239ABE.

14 Section 239ABK.

15 Section 239ABL.

16 Heath and Whale, above n 3, at [17.6].

17 At [17.6].

18 Companies Act, s 239AT and 239AV.

19 Section 239ABA

20 Australian Securities \& Investments Commission "Deed of company arrangement for creditors" (11 August 2020) <www.asic.gov.au>. 
being dependent on the company they relate to. ${ }^{21}$ However, DOCAs often involve some sort of compromise of debts, typically through delayed repayment. ${ }^{22}$ The deed itself must be executed within 15 working days of the watershed meeting. ${ }^{23}$ Once executed, the DOCA is binding on the company, its officers and shareholders, the deed administrator and all creditors who have claims arising on or before the specified "cut-off day", ${ }^{24}$ including those that voted against it, assuming the requisite voting threshold is achieved. ${ }^{25}$

That being said, a DOCA will not prevent secured creditors from enforcing or otherwise dealing with the property they have a charge over, provided they did not vote in favour of executing the DOCA at the watershed meeting. ${ }^{26}$ The court may order such creditors to be bound, regardless of their vote, if the success of the DOCA would be materially adversely affected if the order was not made, provided the creditors' interests are "adequately protected". ${ }^{27}$

The "transition" phase involves the company moving out of administration and into the decided option. ${ }^{28}$

\section{B The Relevance of Voluntary Administration in Australia}

VA was introduced in Australia in 1993, 14 years before it was introduced in New Zealand. New Zealand's VA scheme was very closely modelled on Australia's, albeit with small (but notable) differences. ${ }^{29}$ The substantial replication of Australia's VA scheme in New Zealand warrants an investigation into the background of VA in Australia. Many of the concerns and aspirations regarding VA in Australia are directly transferable to a New Zealand context.

21 Colin Anderson "Ending a Means to an End: Transition from the Voluntary Administration Process to a Deed of Company Arrangement or Liquidation" (2004) 23 U Tas LR 15 at 18.

22 At 18.

23 Companies Act, s 239ACO.

24 The "cut-off day" is defined in s 239ACN(2)(i) as the day on or before which creditors' claims must have arisen if they are to be admissible under the deed.

25 Heath and Whale, above $\mathrm{n}$ 3, at [17.94].

26 Companies Act, s 239ACT(2)(a).

27 Section 239ACV.

28 Heath and Whale, above n 3, at [17.6].

29 (26 October 2006) 634 NZPD 6171 


\section{VOLUNTARY ADMINISTRATION IN AUSTRALIA}

\section{A Law Reform}

Prior to Australia's introduction of VA in 1993, the only corporate rescue procedures available in Australia were schemes of arrangement and official management. ${ }^{30}$ Schemes of arrangement were considered time consuming and expensive, and official management was not often used. ${ }^{31}$ The only other formal schemes available were receivership and liquidation. ${ }^{32}$ The Australian Law Reform Commission conducted a review into insolvency law, and published a report titled the General Insolvency Inquiry (better known as the "Harmer Report") in 1988. The Commission found the existing schemes too conservative, with not enough focus on saving businesses. ${ }^{33}$ The Commission recommended implementing a new voluntary procedure for insolvent companies. ${ }^{34}$

The Australian Government implemented the recommendations of the Harmer Report in the Corporate Law Reform Act 1992, abolishing the official management scheme and replacing it with VA. ${ }^{35}$ The Australian law relating to VA can now be found in pt $5.3 \mathrm{~A}$ of the Corporations Act 2001 (Cth).

\section{B The Australian Experience with Voluntary Administration}

Initially, VA was generally well-received and relatively widely used in Australia. ${ }^{36}$ The graph below uses data taken from the Australian Securities and Investments Commission (ASIC), relating to companies that entered into external administration between 1999-2019. ${ }^{37}$

30 Andrew Sellars Corporate Voluntary Administration in Australia (paper presented to the Forum for Asian Insolvency Reform, Bali, February 2001) at 1.

31 At 1 .

32 At 1 .

33 Australian Law Reform Commission General Insolvency Inquiry (ALRC R45, 1988) at 28.

34 At 28 .

35 Sellars, above $\mathrm{n} 30$, at 1

36 Parliamentary Joint Committee on Corporations and Financial Services Corporate Insolvency Laws: A Stocktake (Commonwealth of Australia, June 2004) at 73.

37 Australian Securities and Investments Commission Insolvency Statistics - Series 1 Companies Entering External Administration (July 2020). 
Figure 1:

\section{COMPANIES THAT HAVE ENTERED INTO EXTERNAL ADMINISTRATION IN AUSTRALIA}

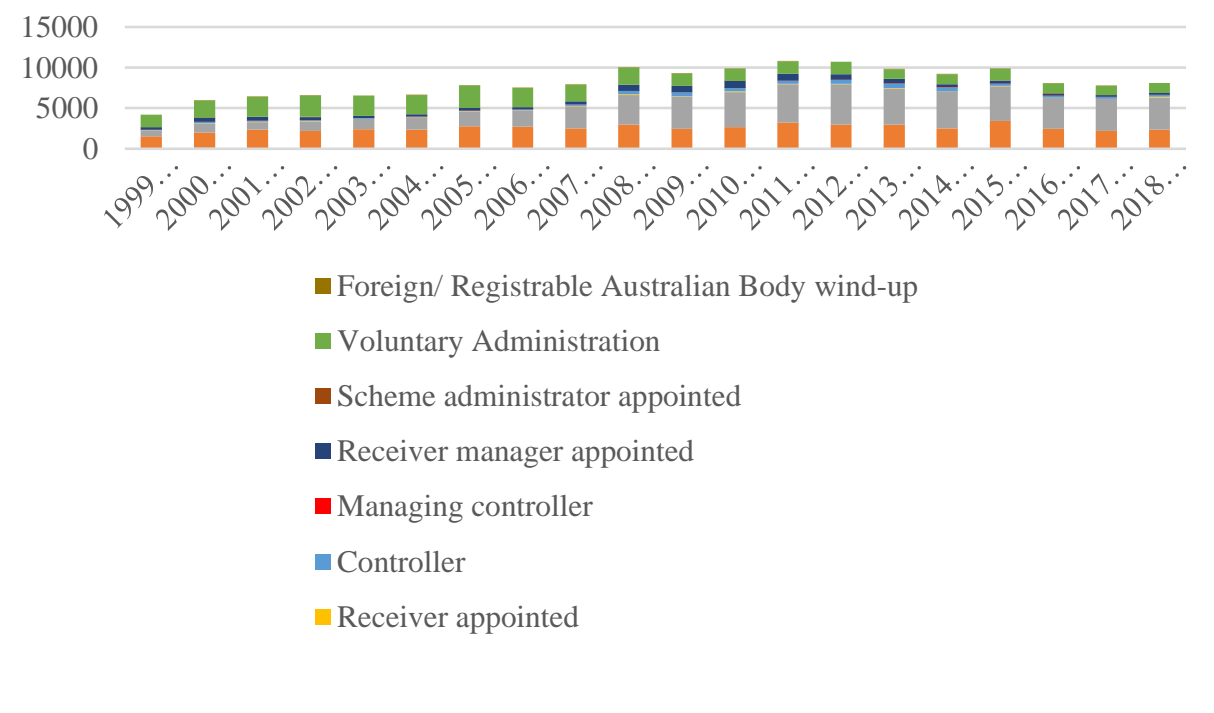

Between 2001-2002, VA accounted for 38 per cent of all corporate insolvency appointments in Australia. ${ }^{38}$ Recently, the use of VA has declined, accounting for 15 per cent of corporate insolvency appointments between 2018-2019. Creditors' wind-up is now the most popular form of external administration in Australia, making up 49 per cent of all corporate insolvency appointments between

38 Jason Harris "Should Voluntary Administration Remain a One-size-fits-all Procedure? Do We Need a Fast Track System for Small Business Rescues?" in Shelley Griffiths, Sheelagh McCracken and Ann Wardrop (eds) Exploring Tensions in Finance Law: Trans-Tasman Insights (Thomas Reuters, Wellington, 2014) 101 at 105 . 
2018-2019. While there is no equivalent to creditors' wind-up in New Zealand, it is comparable to creditors resolving to appoint a liquidator at the watershed meeting. ${ }^{39}$

The initial uptake and recent decline in the use of VA in Australia may be a result of the Australian director penalty notice provisions. The director penalty regime was a substitute for the Australian Taxation Office's (ATO) priority status during liquidation. ${ }^{40}$ The regime allows the ATO to recover outstanding company debts from directors. Before commencing proceedings to recover these debts, the ATO must give directors a Director Penalty Notice (DPN) outlining, among other things, the amount owed. ${ }^{41}$ Once a DPN has been given, directors have 21 days to have any of the penalties stated on the DPN remitted, ${ }^{42}$ which can be done by appointing an administrator or a liquidator or complying with the obligation. ${ }^{43}$

Before the Tax Laws Amendment (Transfer of Provisions) Act 2010 (Cth) came into force, the time period available for directors to remit a penalty was 14 days. Commencing a voluntary liquidation was more time consuming than entering VA, so VA was often used by directors to address DPNs. ${ }^{44}$ Extending the time period to 21 days, and making the liquidation process less time consuming, has likely caused some of the decline in the use of VA and uptake in creditor wind-ups in Australia. ${ }^{45}$

A 2015 report by the Australian Government Productivity Commission found VA was not promoting effective restructuring. ${ }^{46}$ Using data from ASIC, the report found 78 per cent of companies were deregistered within five years of entering VA. ${ }^{47}$ The Productivity Commission stated that "[t]he current culture, incentives and legal framework around voluntary administration inhibit its effectiveness as a genuine restructuring mechanism". ${ }^{48}$

39 Harris, above n 38, at 105.

40 Sylvia Villios "Director penalty notices - promoting a culture of good corporate governance and of successful corporate rescue post insolvency" (2015) 25(2) Revenue LJ 1 at 2.

41 Taxation Administration Act 1953 (Cth), sch 1 division 269-25.

42 Australian Taxation Office "Recovering director penalties" (24 June 2020) <www.ato.gov.au>.

43 Taxation Administration Act, sch 1 division 269-35.

44 Harris, above n 38, at 105.

45 At 105

46 Australian Government Productivity Commission Business Set-up, Transfer and Closure (Final Report 75, 30 September 2015) at 363.

47 At 363

48 At 36 . 
Despite this, the Productivity Commission did not consider a "wholesale change" to the regime necessary. ${ }^{49}$ Rather, it favoured "specific reforms". ${ }^{50}$ One of these reforms was a requirement for an administrator to certify, within one month of their appointment, that they have reasonable grounds to believe the company is capable of being a viable business. ${ }^{51}$ If the company is not deemed capable, the Productivity Commission recommended that the administrator should be under a duty to appoint a liquidator. ${ }^{52}$ The Australian Government chose not to support this recommendation in its response to the Productivity Commission's report in $2017 .{ }^{53}$

\section{THE BACKGROUND TO VOLUNTARY ADMINISTRATION IN NEW ZEALAND}

Prior to 2007, there were two statutory procedures available in New Zealand allowing companies to enter into arrangements with creditors:

(a) creditor compromise (pt 14 of the Companies Act); and

(b) court-ordered compromise (pt 15 of the Companies Act). ${ }^{54}$

\section{A The 2001 Law Commission Report}

In 2001, the New Zealand Law Commission published a report reviewing the law relating to insolvency in New Zealand and proposed a new rehabilitation regime be developed. ${ }^{55}$ The Commission intended the scheme to be targeted at large businesses, with "small to medium sized businesses" (SMEs) ${ }^{56}$ being able to use the regime, provided they met certain entry criteria. ${ }^{57}$

\footnotetext{
49 At 36.

50 At 36.

51 At 36 .

52 At 37.

53 The Australian Government Treasury The Australian Government Response to the Productivity Commission Inquiry into Business Set-Up, Transfer and Closure (May 2017) at 23.

54 Law Commission Insolvency Law Reform: Promoting Trust and Confidence (NZLC SP11, 2001) at 70.

55 At 84.

56 At 27.

57 At 84.
} 


\section{B Law Reform}

The New Zealand Labour Government of the time saw the existing rehabilitation schemes as expensive, underused and ineffective. ${ }^{58}$ VA was intended to serve as an alternative to liquidation, ${ }^{59}$ providing an opportunity for businesses on the verge of insolvency to develop a plan to trade on. ${ }^{60}$ If rehabilitation was not possible, VA was intended to provide time to liquidate the business in a way that reduced the social and economic impacts associated with business failure. ${ }^{61}$

These objectives were embodied in the Insolvency Law Reform Bill 2005 (the Bill). Much of the Hansard surrounding the Bill concerned VA, in particular, the retention of the Inland Revenue Department's (IRD) status as a preferential creditor. ${ }^{62}$ Unlike the Australian regime, the IRD remains a preferential creditor if the company is placed into liquidation following the administration. ${ }^{63}$ There was concern the retention of the IRD's preferential status would hamper VA's effectiveness. It was proposed by the New Zealand National Party (National) that the IRD would be motivated to vote against a DOCA, as it would likely recover more as a preferential creditor in a liquidation, rather than agreeing to a DOCA with other creditors. ${ }^{64}$ The Bill passed without National's support, and now forms pt $15 \mathrm{~A}$ of the Companies Act.

\section{RESEARCH INTO VOLUNTARY ADMINISTRATION IN NEW ZEALAND}

This article analyses the results of research undertaken into the use of VA in New Zealand. The general aim of this research was twofold. First, it aimed to determine how often VA has been used as an insolvency procedure in New Zealand. Second, it examined the status of companies post entering VA.

\section{A Methodology}

The necessary data was provided by the New Zealand Companies Office which included details on all companies that went into VA in the research period. The data is up to date as of 28 February 2020, and includes information from 265 companies that had entered into VA since the scheme was

\footnotetext{
58 Lianne Dalziel "Insolvency Law Reform - Voluntary Administration" (Speech to INSOL, 1 March 2006).

59 (26 October 2006) 634 NZPD 6171

60 Dalziel, above n 58.

61 Dalziel, above n 58.

62 (5 September 2006) 633 NZPD 5175.

63 Companies Act, sch 7.

64 (26 October 2006) 634 NZPD 6171.
} 
introduced in 2007. While introduced in 2007, the first VA did not take place until February 2008. This is not surprising given pt 15A of the Companies Act came into force in November 2007.

The data provided by the Companies Office did not include:

(a) the watershed meeting dates, or the outcome of the watershed meetings;

(b) whether a receiver had been appointed; and

(c) whether the company had been returned to its directors.

This information was obtained by searching the companies register using the company numbers provided in the data from the Companies Office.

As of 28 February 2020, only one company had entered into VA in 2020. A decision was made to exclude this company from the current analyses, so only data from complete years (2008-2019) was included. It should also be noted that the status of some of the companies will have changed since writing this article.

A decision was also made to exclude any information on the cost of VA per company because this information was not available on the companies register for many companies. Furthermore, the extended period of time the data relates to (2008-2019) means that any figure may not accurately reflect the cost of VA in 2020. Instead, practitioners within the insolvency industry were asked what they considered the price of an average VA to be.

The percentages used in the infographics are rounded to the nearest whole number. They are obtained by dividing the number of companies in each relevant status or category by the total number of companies.

Finally, the results of the research have a potential sample bias, in that only companies suffering from some type of financial difficulty are likely to enter VA. This means companies entering VA are more likely to be removed from the companies register than the broader stock of companies. ${ }^{65}$

\section{B Prior Research}

There have been surprisingly few quantitative studies into VA in New Zealand. Some relatively recently studies have been conducted in Australia, including studies by James Routledge and David Morrison in $2009^{66}$ and $2012 .{ }^{67}$ This author is aware of two other reviews into the outcomes of VA

65 Australian Government Productivity Commission, above n 46, at 363.

66 James Routledge and David Morrison "Voluntary administration: Patterns of corporate decline" (2009) 27 C\&SLJ 95

67 James Routledge and David Morrison "Insolvency administration as a strategic response to financial distress" (2012) 37 Aust J Manag 441. 
in New Zealand. The first was undertaken by Professor Michael Gedye in $2014,{ }^{68}$ and the second was undertaken by Simpson Grierson (law firm) in May 2019 as part of a presentation to the Restructuring Insolvency and Turnaround Association New Zealand. ${ }^{69}$

\section{RESULTS OF THE RESEARCH INTO VOLUNTARY ADMINISTRATION IN NEW ZEALAND}

The results of the research were formulated to answer the following questions:

(a) How many VAs have there been since VA was introduced?

(b) What is the status of companies post entering VA?

(c) What is the status of companies post entering into Deed of Company Arrangements (DOCAs)? And what is the status of those that did not enter a DOCA?

(d) What were the outcomes of watershed meetings?

(e) What are the cost implications of entering VA?

68 Fiona Rotherham "The vexed question of voluntary administration" (27 October 2017) National Business Review <www.nbr.co.nz>.

69 Reweti Kohere "Underused voluntary administration needs revamp" (24 May 2019) National Business Review <www.nbr.co.nz>. 


\section{A How Many Companies Have Entered into VA since the Regime was Introduced?}

Figure 2:

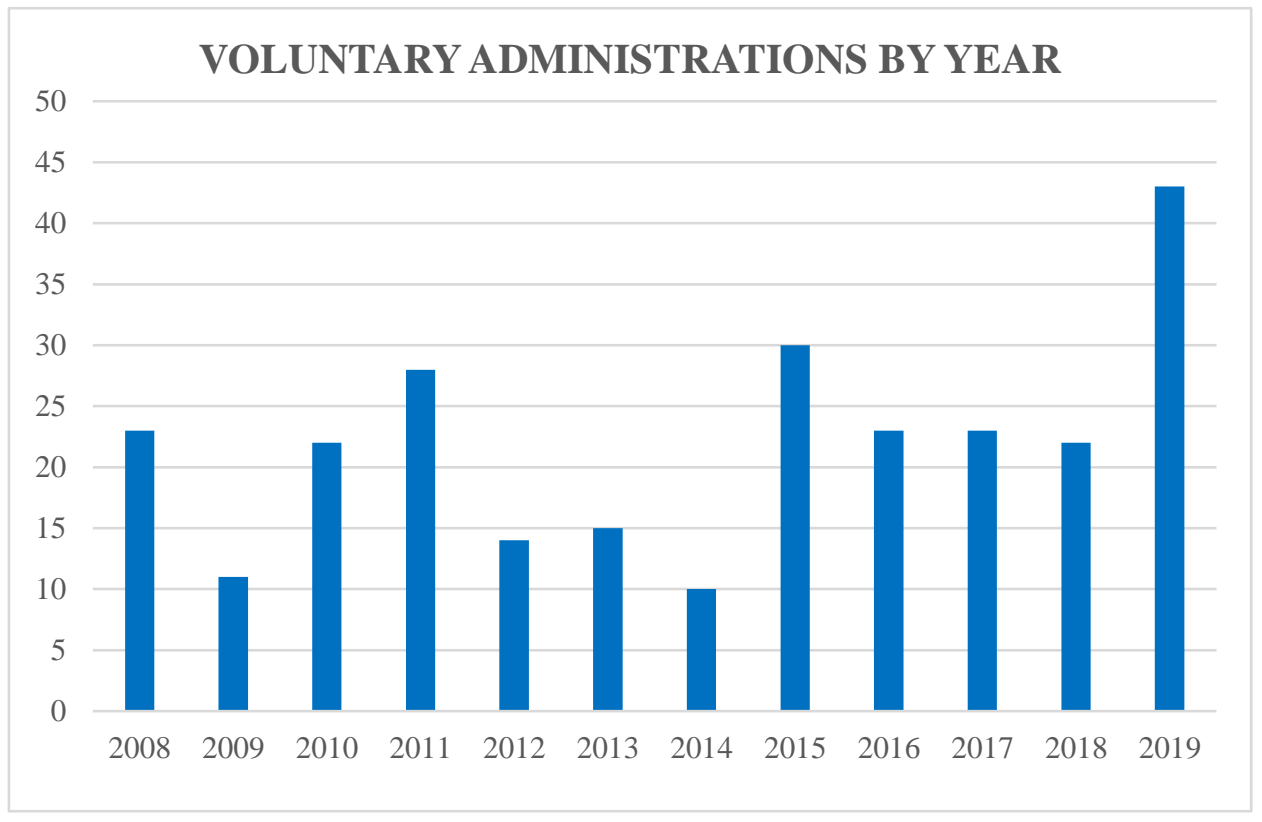

264 companies entered VA during 2008-2019, an average of 22 companies per year. There was a large increase (43) in VAs in 2019. The economic impact of COVID-19 will likely result in a further increase in the number of companies that enter VA in 2020 and beyond. Despite the recent increase in the use of VA, it remains substantially underused in comparison to other insolvency procedures (see below). 
Figure 3:

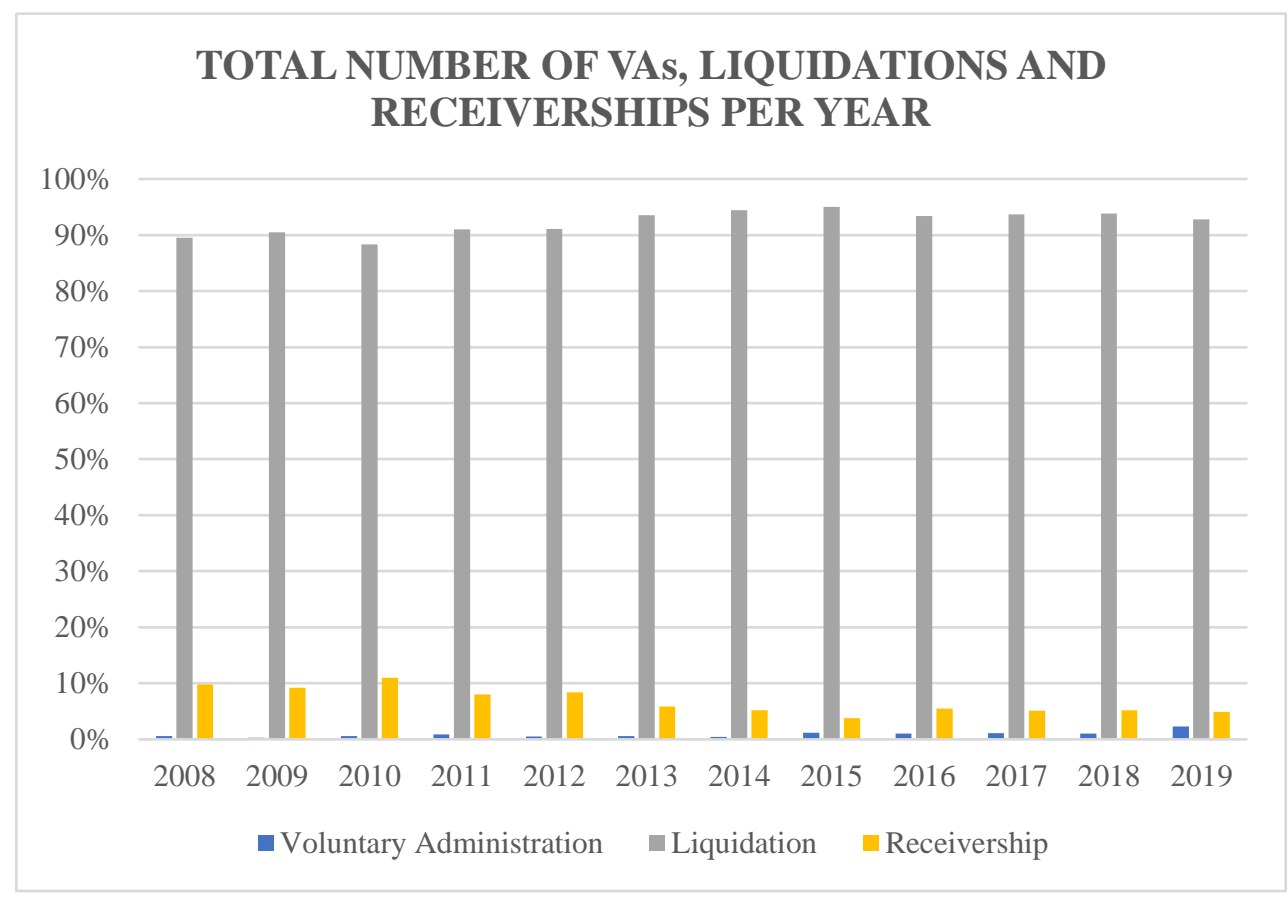

With the exception of 2019 ( 2.3 per cent), VAs consistently made up less than one per cent of the total number of companies that entered into insolvency procedures per year. Liquidation remains the most common procedure, making up an average of 91 per cent of the total number of companies. Receivership is a distant second, averaging seven per cent of companies. ${ }^{70}$

These figures are to be used as a guide only. One consideration that has not been taken into account is the fact that a company may move between various statuses over the years, and therefore may reenter the same status at a subsequent date.

70 Percentages were determined by dividing the amount of liquidations, receiverships and VAs in each year from 2008-2019 by the total number of companies that entered into liquidation, receivership or VA in each year during the same time period. 


\section{$B$ What is the Status of Companies post Entering into VA?}

Figure 4:

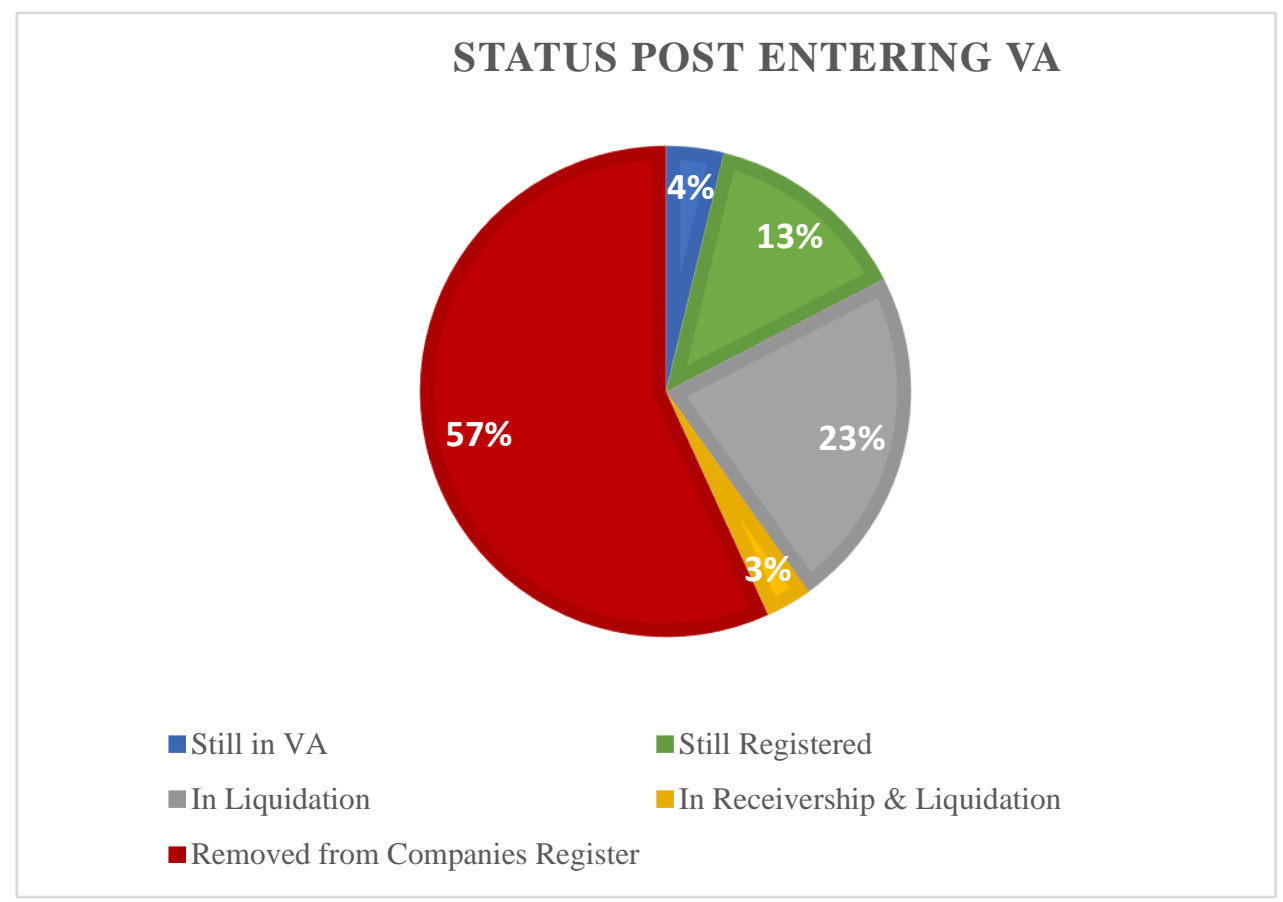

57 per cent of the 264 companies that entered into VA have since been removed from the companies register. 23 per cent are in liquidation and three per cent are in receivership and liquidation. Four per cent are currently in VA and 13 per cent remain registered. This data indicates that removal from the companies register (likely after liquidation) is the most common outcome of VA. Given liquidation is a terminal procedure, 83 per cent of companies that went into VA during the research period will not continue to exist after entering VA. ${ }^{71}$

71 Includes "removed from companies register" (57 per cent), "in liquidation" (23 per cent) and "in receivership and liquidation" (three per cent). 
C What is the Status of Companies post Entering a DOCA? And What is the Status of Those That Did Not Enter a DOCA?

Figure 5:

STATUS POST ENTERING DOCA

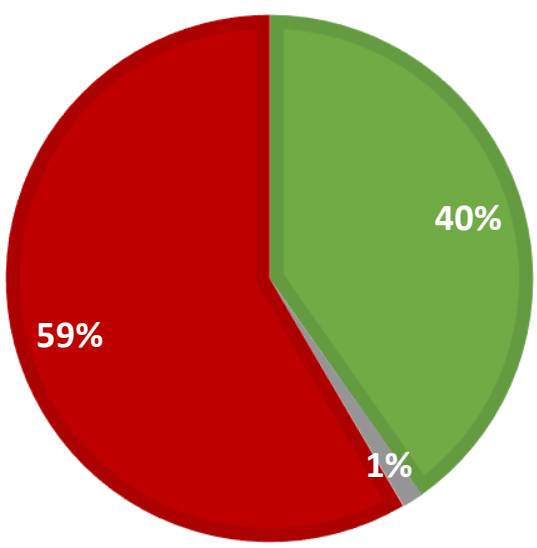

- Still Registered $\quad$ In Liquidation $\quad$ Removed from Companies Register

Excluding companies currently in VA, 77 companies ( 30 per cent) entered into a DOCA. Of these companies, 59 per cent are now removed from the companies register, 40 per cent are registered and one per cent are in liquidation.

Fig. 6:

\section{STATUS AFTER NO ENTRY INTO DOCA}

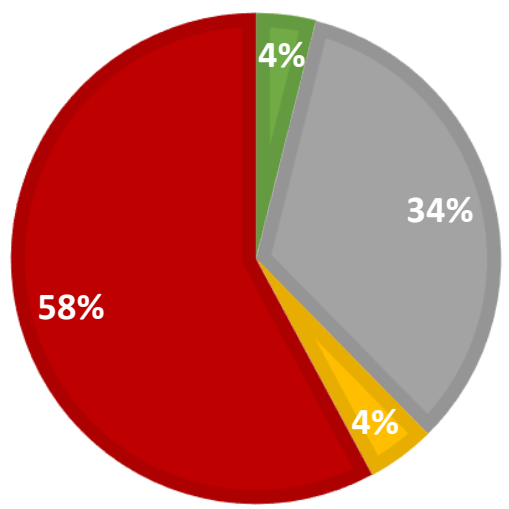

- Still Registered

- In Receivership and Liquidation
- In Liquidation

- Removed from Companies Register 
Also excluding companies currently in VA, 177 companies (70 per cent) that entered VA did not enter into a DOCA. Of these companies, 58 per cent are now removed from the companies register, 34 per cent are in liquidation, four per cent are in receivership and liquidation and four per cent are still registered.

\section{What were the Outcomes of the Watershed Meetings?}

Figure 7:

\section{OUTCOME OF WATERSHED MEETINGS}

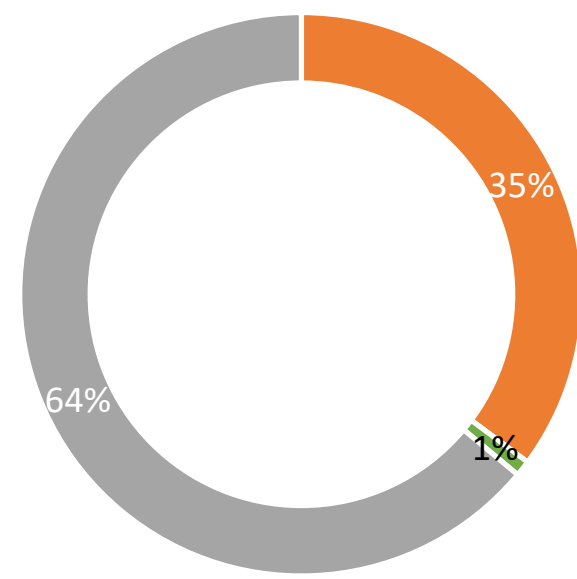

- DOCA - Returned to Directors " Liquidation

Again, excluding companies currently in VA, 219 of the 254 companies that entered VA made it to the watershed meeting. Of these, 64 per cent were placed into liquidation, 35 per cent executed a DOCA, and one per cent were returned to the directors of the company.

The liquidation figures were determined by taking the total number of companies that made it to a watershed meeting (219) and subtracting those that executed DOCAs (77) and those that had been returned to the directors (two). The balance (140) represents those placed into liquidation. This can be calculated because liquidation, executing a DOCA and returning the company to its directors, are the only three available outcomes of a watershed meeting. 
A company could be returned to its directors at the watershed meeting (or enter into a DOCA), then subsequently placed into liquidation. These companies would be included in the liquidation data set. Companies were only included as being returned to directors when there was clear evidence on the companies register of such a decision being made at the watershed meeting. Companies that were returned to directors through other means (such as the VA being vacated) were not included in the "returned to directors" data set.

\section{$E$ What are the Cost Implications of Entering into VA?}

As previously stated, it is not possible to determine (with any accuracy) the cost implications of entering VA using information available on the companies register. There has been some research into the cost of VA in Australia. Jason Harris in his chapter in Exploring Tensions in Finance Law: Trans-Tasman Insights suggests there is anecdotal evidence that Australian VAs can cost AUD 50,000 at a minimum. ${ }^{72}$ A sample review of DOCAs, conducted by Mark Wellard in 2014, found the average remuneration of Australian administrators to be AUD 54,670. ${ }^{73}$

These figures are consistent with anecdotal evidence from insolvency practitioners in New Zealand made available to this author. Insolvency practitioners suggested an average VA in New Zealand can cost between NZD 50,000-60,000. It is important to note that these figures are an approximation only. The cost will largely depend on the circumstances of the company entering VA.

The cost of appointing an administrator may be high due to the personal liability administrators incur in undertaking administration, ${ }^{74}$ and the relatively small pool of qualified and experienced practitioners. ${ }^{75}$ Setting up and running the two required creditors' meetings can also be costly. ${ }^{76}$

\section{AN ANALYSIS OF THE RESULTS OF THE RESEARCH}

The findings of the current research can be summarised into four key points:

(1) VA has been used far less than other insolvency procedures.

(2) The majority of companies that entered VA were liquidated and then removed from the companies register.

(3) More companies remained registered after executing a DOCA.

(4) Most watershed meetings resulted in the company being placed into liquidation.

72 Harris, above n 38, at 111.

73 Mark Wellard A sample review of Deeds of Company Arrangement under Part 5.3A of the Corporations Act (2013 ARITA Terry Taylor Scholarship Report, Queensland University of Technology, 2017) at 17.

74 Companies Act, ss 239ADH-239ADI and s 239Y(3).

75 Harris, above n 38, at 110.

76 Kohere, above n 69. 
Potential reasons for these findings will be discussed in turn. However, it should be noted that it is difficult to establish with certainty why VA has operated in the way it has. This is primarily due to the limited amount of information available on the companies register, which often does not include information such as the intended outcome of the VA or the financial position of the company before entering VA. The following reasons for the above findings are by no means intended to be exhaustive or conclusive.

\section{A VA has been Used Far Less than Other Insolvency Procedures}

\section{Cost barriers}

A potential reason why VA has been used less frequently than other insolvency procedures may be due to the number of small businesses in New Zealand. The Law Commission's 2001 report recognised that New Zealand's economy was overwhelmingly populated by SMEs. ${ }^{77}$ The Commission noted that "[t]he predominance of small businesses in New Zealand raises questions about the cost effectiveness of current and potential insolvency regimes". ${ }^{78}$ While VA is available to all companies who wish to use it, the cost of implementing VA may serve as a barrier for small businesses already facing financial difficulty.

For these small businesses, liquidation may be a more cost-efficient option, as the liquidator will shut down the business quickly or continue to trade for only a short amount of time. ${ }^{79}$ This reduces the cost of professional fees, in comparison to VA, where an administrator may continue to trade for a longer period of time ${ }^{80}$ The cost of VA is relative. For large businesses with substantial assets, cost is not such an impediment to entering into VA. ${ }^{81}$ However, the majority of businesses in New Zealand are not these large businesses, which means the cost of VA may serve as a barrier to using the scheme.

\section{Lack of confidence by fully secured creditors}

The underuse of VA may also be due to a lack of confidence in the scheme by fully secured creditors. Receivers are commonly appointed by these creditors, such as banks with General Security Agreements (GSAs) using the power to act within the 10 working day period. ${ }^{82}$ For these creditors, VA may present an unnecessary risk, as appointing a receiver ensures a quicker return to that creditor

77 Law Commission, above n 54, at 27.

78 At 28.

79 Harris, above n 38, at 111.

80 At 111 .

81 Kohere, above n 69.

82 Michael Harper "Receiverships" (1 April 2008) Chapman Tripp <www.chapmantripp.com>. 
of as much as possible of their debt. ${ }^{83}$ Such creditors may be unwilling to forgo their rights by entering into a DOCA with other creditors, unless they are confident they will get a better return in doing so. Entering VA may, in fact, diminish the pool of assets available to satisfy the debt, resulting in a lower return than what would have been possible through appointing a receiver.

\section{$B$ Most Companies that Went into VA were Liquidated and Removed from the Companies Register}

1 VA may have been misused

VA was intended to provide an opportunity for businesses on the verge of insolvency to regroup and develop a plan to continue to trade, rather than liquidating. ${ }^{84}$ If a company is already terminally insolvent before an administrator is appointed, the outcome of VA will almost always be liquidation.

In this sense, timing is crucial. Companies should enter VA when there is still a core, sustainable business for the administrator to work with. If things are left for too long, and the company has no good assets or viable business left, it can be argued that VA should not be used, as it will invariably serve as a pathway to liquidation. The same can be said for companies that could never be rehabilitated in the first place, perhaps due to a critical flaw in the business model.

It is difficult to pin down why the VA model may have been misused in such a way. One reason may be due to the personal involvement of directors in their companies. Small businesses are often owned and operated by the directors of the company. ${ }^{85}$ These directors often have personal wealth tied up in the businesses and a sentimental attachment to the business they have built. ${ }^{86}$ This may result in directors running their business past the point of terminal insolvency, and then looking to VA as some sort of "Hail Mary" that will save their business. ${ }^{87}$

Section 301(4) of the Companies Act may also provide a perverse incentive for directors to enter VA. Under s 301(4), the court must, when relevant, consider the director's conduct in initiating VA when determining whether it should make an order requiring the director to repay money, restore property or contribute to the assets of the company under s 301(1)(b). Directors may use VA as a "safe harbour" from personal liability, as entering VA may be a mitigating factor the court considers

83 Jonathan Barrett and Ronán Feehily Understanding Company Law (4th ed, LexisNexis, Wellington, 2019) at [14.6.4].

84 Dalziel, above n 58

85 Harris, above n 38, at 112.

86 At 112.

87 At 112. 
when making an order under s $301 .{ }^{88}$ This might lead to VA being used to avoid personal liability, rather than as a genuine business rehabilitation mechanism. ${ }^{89}$

If directors have used VA for reasons outside the objectives in pt $15 \mathrm{~A}$ of the Companies Act, it is difficult for the administrator (once appointed) to develop a successful rehabilitation plan. Successful rehabilitation requires the co-operation of the directors working alongside the administrator with the shared objective of the business continuing to exist. ${ }^{90}$ If the company's directors are not on board, perhaps because they never truly intended to use VA to rehabilitate the business, it is likely the company will ultimately be placed into liquidation.

The misuse of VA may have been encouraged by insolvency practitioners accepting appointments in circumstances when they should not have. Administrators might accept an appointment, knowing their fees take priority in a liquidation, despite also knowing the company is at the stage where liquidation is the best option. The previous lack of regulation of insolvency practitioners may have been an enabler for this procedural abuse. ${ }^{91}$

\section{Liquidation may have been the desired outcome}

It is important to recognise that liquidation is not inherently a bad outcome of VA. ${ }^{92}$ The second objective of pt $15 \mathrm{~A}$ of the Companies Act is for VA to achieve a better return for creditors than what would have been possible through immediate liquidation. ${ }^{93}$ For some VAs, the appointment of an administrator may have been part of a "pre-pack" agreement between the company and its creditors, where the intent was always to liquidate the company after the administration ended. A notable example of such an arrangement is Solid Energy New Zealand Ltd. It was estimated that putting Solid Energy into immediate liquidation would have provided creditors with a return of only 15-20 cents for every dollar they were owed. ${ }^{94}$ However, after entering VA - aided by an increase in coal prices

88 Heath and Whale, above n 3, at [17.8].

89 David Brown Corporate Rescue: Report for the Ministry of Economic Development (Ministry of Economic Development, November 2000).

90 BWA Insolvency "Voluntary Administration" (26 July 2018) <www.bwainsolvency.co.nz/>.

91 See the Insolvency Practitioners Regulation Act 2019. Administrators are now required to hold a licence (that may be cancelled if certain requirements are not met) issued by an accredited body.

92 Rotherham, above n 68.

93 Companies Act, s 239A(b).

94 Rotherham, above n 68. 
- major creditors were paid out close to 60 cents for every dollar owed. ${ }^{95}$ Clearly, this was a much better result than the return possible through immediate liquidation.

\section{The appointment of receivers commonly makes liquidation inevitable}

A lack of confidence by fully secured creditors (often banks) means receivers are often appointed over top of administrators. The administration can continue over any assets that are not subject to the fully secured creditor's charge. ${ }^{96}$ However, if the fully secured creditor is (for example) a bank with a GSA over all present and after acquired property, the administrator will have limited (if any) assets to work with. Once the receivership is complete, the administrator is left with far less working capital, and often little choice but to recommend liquidating the company's remaining assets.

The registration of Purchase Money Security Interests (PMSIs) may also cause companies to be placed into liquidation following VA. Administrators are unable to use assets with a PMSI attached to them to recover the costs of running the business during the administration. ${ }^{97}$ If many of the company's substantial assets are subject to a PMSI, the inability to use these assets to cover the cost of running the business may make it difficult for the administrator to restructure the company to maximise its chances of continuing to trade. This makes liquidation the likely outcome.

\section{More Companies Remained Registered after Entering into a DOCA}

The current findings suggest that the execution of a DOCA increases a company's chance of remaining registered. The ability to continue to trade is an obvious reason why more companies remain registered after executing a DOCA. The existence of a DOCA also means the company has the support of the majority of its creditors. This support allows the company to retain supply agreements, enabling it to attempt to trade out of insolvency. The execution of a DOCA is also an indication that the majority of creditors are confident the company will be able to recover, or will provide a better return, otherwise a liquidator would have been appointed. It follows that companies that enter DOCAs will often have better potential to recover, increasing the likelihood of them remaining registered.

While DOCAs may improve a company's chance of remaining registered (in comparison to a company that does not enter a DOCA), the majority of companies that entered into DOCAs in this research were subsequently removed from the companies register. DOCAs can be effective, but do not guarantee the survival of the company.

95 Rotherham, above n 68.

96 Heath and Whale, above n 3, at [17.8].

97 Damien Grant "Insolvency in New Zealand" Waterstone Insolvency <www.waterstone.co.nz> at 56. 


\section{$D$ The Outcome of Most Watershed Meetings was the Company Being Placed into Liquidation}

As previously outlined, if a company in VA makes it to the watershed meeting, there are three possible outcomes:

(a) liquidation;

(b) ending the administration and returning the company to its directors; or

(c) executing a DOCA. ${ }^{98}$

For the vast majority of VAs, returning the company to its directors is not a viable option. This is, in part, due to the relatively short 25 working day period between the appointment of an administrator and the watershed meeting. ${ }^{99}$ In this short time frame, it is unlikely the company's position would have changed enough to justify ending the administration and returning the company to its directors at the watershed meeting. This would typically only happen if the appointment of an administrator was unnecessary in the first place.

Therefore, in almost all VAs, creditors are left to decide at the watershed meeting whether to appoint a liquidator or execute a DOCA. The threshold for a resolution to be adopted is more than 50 per cent in number, which represents at least 75 per cent in value of the debt owed. ${ }^{100}$ While the results of the current research suggest DOCAs improve the likelihood of a company remaining registered after entering VA, creditors may be unwilling to approve a DOCA for a number of reasons. Fully secured creditors (who often represent over 26 per cent in value of what is owed) may be unwilling to support a proposal under a DOCA, preferring instead to exercise their existing rights.

In addition, the IRD's preferential status in a liquidation means it may be unwilling to support a DOCA. ${ }^{101}$ By supporting a DOCA, the IRD may forgo its existing rights, becoming bound by the terms of the DOCA alongside other creditors. ${ }^{102}$ The IRD's unwillingness to support a DOCA may act as a reason for most watershed meetings resulting in the company being placed into liquidation.

That being said, the IRD will consider a range of factors when deciding whether to support a DOCA including: the likelihood of compliance with the terms of a proposal; whether the proposal

98 Companies Act, s 239ABA.

99 Sections 239AT and 239AV. But see s 239AT(3) that provides that the 25 working day period can be extended by a court order on the administrator's application.

100 Section 239AK.

101 Companies Act, sch 7.

102 (26 October 2006) 634 NZPD 6171. 
will provide a maximum return; and the nature of other debt owed to creditors. ${ }^{103}$ The IRD's decision at the watershed meeting will likely hinge on whether it believes a better return is possible through placing the company into liquidation, or allowing the company to continue to trade under a DOCA.

A further reason why DOCAs may be difficult to get approved relates to potential distrust on behalf of creditors. In some cases, the appointment of an administrator may be the first indication of the company's financial difficulties to creditors. This may come as a shock to creditors, who will understandably be wary of initiating new transactions with the company. Creditors who find themselves in this position may prefer to cut their losses and recover what they can through liquidation, rather than agreeing to a recovery plan that (in their mind) may result in a lower return on the money they are owed.

\section{IS VOLUNTARY ADMINISTRATION MEETING ITS OBJECTIVES?}

VA was intended to be more cost-effective and widely used than the rehabilitation schemes that were previously available. ${ }^{104}$ It was meant to help companies trade out of insolvency and, when this is not possible, create a better result for the company and its creditors than what would have been possible through liquidation. ${ }^{105}$

\section{A VA's Use and Cost}

VA remains the least used formal insolvency procedure in New Zealand. While the use of VA has also declined in Australia, it still made up, on average, over 15 per cent of external administration appointments from 2007 to 2019 - a far cry from the one per cent of companies that entered VA in New Zealand during the same period. ${ }^{106}$ The use of other rehabilitation schemes (such as creditor compromise and court ordered compromise) has not been investigated in this article. However, up until 2002, there was an average of 20 compromises with creditors each year. ${ }^{107}$ By contrast, an average of 22 companies entered into VA each year in New Zealand from 2007-2019. This anecdotal evidence suggests that VA has not been more widely used than the other rehabilitation schemes. While the cost of these other rehabilitation schemes has also not been investigated, the VA regime, as it stands today, does not appear to be cost effective, especially for small businesses.

103 Policies regarding Voluntary Administrations in New Zealand (9 February 2015) (obtained under the Official Information Act 1982 request to the Inland Revenue Department).

104 Dalziel, above n 58.

105 Companies Act, s 239A.

106 Australian Securities \& Investments Commission, above n 37.

107 Dalziel, above n 58. 


\section{B Maximising the Company's Chance of Continuing to Exist}

The results of the current research demonstrate that most VAs do not result in the company continuing to exist. This is because the vast majority of companies that entered VA were liquidated, then removed from the companies register. Based on this evidence, VA is not meeting its first objective.

\section{Resulting in a Better Return than What would have been Possible from Immediate Liquidation}

Whether this objective has been met is more difficult to determine, especially when only using information available on the companies register. It is certainly possible for VA to result in a better return than what would have been possible from immediate liquidation, as evidenced by the Solid Energy administration. The difficulty lies in ascertaining whether VA would in fact result in a better return, which is an issue that has been addressed in limited case law.

In Strategic Options Ltd v Swordfish Lodge Management Ltd, Associate Judge Doogue interpreted "likely to result in a better return" broadly. ${ }^{108}$ His Honour found the expression was not limited to receiving income in the short term, but could include maintaining the business as a going concern, allowing the administrator to reduce expenses or restructure the business. ${ }^{109}$ In Haddon v Jackeytown Property 2012 Ltd, Associate Judge Smith - while considering Associate Judge Doogues' approach in Strategic Options Ltd - could not find any evidence on the facts before him that appointing an administrator would result in a better return to creditors than an immediate liquidation. ${ }^{110}$ This demonstrates that whether VA will result in a better return to creditors is very much dependent on each particular company.

For large businesses, the moratorium period and support of an external administrator may enable the company to improve its position before being liquidated, resulting in a better return to creditors. However, for small businesses, the 25-working day-time period may not be long enough for the company's financial position to have improved enough to off-set the cost of VA, meaning VA will often not result in a better return.

The convening period can be extended, but this also comes with costs, further reducing the assets available to be distributed in a liquidation. ${ }^{111}$ Executing a DOCA and then liquidating the company may provide a better return. However, only 27 of the 77 companies that executed a DOCA in the research period were subsequently liquidated. Even if all 27 companies provided a better return to

108 Strategic Options Ltd v Swordfish Lodge Management Ltd [2009] NZCCLR 2 (HC) at [22].

109 At [22].

110 Haddon v Jackeytown Property 2012 Ltd [2015] NZHC 431 at [70]-[73].

111 Companies Act, s 239AT. 
creditors than what would have been possible through an immediate liquidation, it would still only make up 10 per cent of the total number of companies.

\section{A CASE FOR REFORM}

A 2017 report by the Insolvency Working Group briefly considered corporate restructuring processes in New Zealand. ${ }^{112}$ The Working Group did not undertake a broad review of VA in the report, stating "we are not aware of any major issues with those systems [referring to pts 14,15 and $15 \mathrm{~A}$ of the Companies Act] and there is no evidence that wholesale changes are needed."113 Nevertheless, the Working Group recommended that the New Zealand Government continue to monitor and review overseas developments regarding VA. ${ }^{114}$ At this stage, it does not look as though the New Zealand Government is planning on any major reforms to the VA regime.

\section{A Are There Any Issues with the Existing Law?}

While it appears that VA is not meeting at least one of the Companies Act pt 15A objectives, this is not necessarily a reflection of bad law. Part $15 \mathrm{~A}$ is well-structured, relatively clear and easy to follow. The objectives of pt $15 \mathrm{~A}$ are worth keeping. Without a scheme like VA, we are left with insolvency procedures such as liquidation and receivership which focus solely on maximising the return to creditors, as opposed to rehabilitating the business, ${ }^{115}$ and creditor compromises under pts 14 and 15, which have their own issues. ${ }^{116}$ It is suggested the issue with the existing law may not be the law itself, but the way VA has been used by companies in practice.

It is also important to note that, while the research seems to indicate that VA is not operating successfully as a rescue mechanism, this does not necessarily indicate that VA is not meeting its objectives, as VA may be meeting the second objective of pt $15 \mathrm{~A}$ (the better return objective). The following proposals for reform are suggestions for how VA may be improved to increase its use, and how it may be changed to operate more effectively as a rescue mechanism.

\section{B Areas of Reform}

\section{Limiting when and how VA can be used}

A key issue with the existing VA regime is when and how VA is used. Companies may be entering VA too late, using VA when the company has no realistic chance of rehabilitation, or using it to avoid

112 Insolvency Working Group Report No 2 - Voidable transactions, Ponzi schemes and other corporate insolvency matters (Ministry of Business, Innovation and Employment, 15 May 2017) at 40.

113 At 40

114 At 40 .

115 Australian Law Reform Commission, above n 33, at 28.

116 See Law Commission, above n 54, at 80-83; and Dalziel, above n 58. 
personal liability. Changes could be made to ensure VA is entered into at the right time, for the right reasons.

A requirement for an insolvency practitioner to verify at the outset of the VA that there is a real prospect VA would increase the company's chances of trading out of insolvency, or maximise the return to creditors, may ensure VA is used as it was intended. The system of licensing, introduced by the Insolvency Practitioners Regulation Act 2019, should prevent administrators from acting out of self-interest by giving false declarations as to the company's prospects; false declarations may lead to practitioners having their licence cancelled. ${ }^{117}$ However, introducing entry requirements adds extra cost, and provides a disincentive to use an already under-utilised regime. ${ }^{118}$

Providing incentives for directors to use VA only when it is a suitable option may help ensure VA is used as was intended. Making directors personally liable for the costs of the administrator, if VA was clearly not a suitable option in the circumstances, may provide such an incentive. However, in order to do this, s 301(4) of the Companies Act may need to be amended or deleted or clarified by the courts.

It appears s 301(4) was meant to allow the appointment of an administrator to be a mitigating factor in determining whether to make an order under s 301(1). ${ }^{119}$ However, s 301(4) may be interpreted as allowing the court to consider whether appointing an administrator was a genuine attempt to improve the company's position, or whether it was merely to avoid personal liability or to frustrate creditors. Whether the court considers the appointment of an administrator as a mitigating factor against granting an order, or a factor in favour of granting one, could depend on how VA was used by the directors who initiated it.

That being said, even if a court were to consider this interpretation of s 301(4) valid, s 301 does not, of itself, impose duties on directors. ${ }^{120}$ Rather, it operates as a means of enforcement against directors who have (among other things) breached their duty. ${ }^{121}$ A duty directors may breach if they decide to appoint an administrator for the wrong reasons may be s 133 - "A director must exercise a power for a proper purpose". While there does not appear to be any New Zealand case law on this issue, the Federal Court of Australia in Kazar v Duus held: ${ }^{122}$

117 Section 17.

118 Law Commission, above $\mathrm{n} 54$, at 85.

119 Heath and Whale, above n 3, at [17.8].

120 Peace and Glory Society Ltd (in liq) v Samsa [2009] NZCA 396, [2010] 2 NZLR 57 at [47].

121 At [47].

122 Kazar v Duus (1998) 29 ACSR 321 (FCA) at 335-336. 
... the power to appoint an administrator under s 436A [s 239I ${ }^{123}$ must be in furtherance of the object of [p]t 5.3A [pt 15A] as set out in s 435A [s 239A]. Thus, if the power to appoint an administrator is exercised for a purpose unrelated to that object but for an ulterior or extraneous purpose then it will be invalidly exercised.

It is arguable that "power" under s 133 includes the power to appoint an administrator under s 239I, with the required "proper purpose" being to achieve one of the two objectives of pt 15A. ${ }^{124}$

Increasing the avenues for directors to assume personal liability if they misuse VA may incentivise its use as a genuine business rehabilitation tool. However, it could also lead to directors choosing not to use VA at all. There is no straightforward solution to this, and it ultimately comes down to finding a balance between encouraging the use of VA, while also preventing directors from using it purely as a way of escaping liability. ${ }^{125}$

\section{Cost barriers for small companies}

The costs associated with VA means its use is often unjustifiable for small businesses. The cost of VA could be reduced by streamlining the administration process. The current procedure involves two compulsory creditors' meetings: the first creditors' meeting and the watershed meeting. ${ }^{126}$ The first creditors' meeting may not be necessary for all administrations, as it solely concerns appointments. ${ }^{127}$ To make VA more cost effective, the first creditors' meeting could be dispensed with, ${ }^{128}$ as it can be done in a liquidation. ${ }^{129}$

Dispensing with the need to appoint an external administrator could also bring costs down. In the United States, there is a debtor-in-possession regime that allows for the restructuring of companies without the appointment of an external administrator. ${ }^{130}$ A committee of creditors is appointed, whose

123 Inserted are the equivalent New Zealand Companies Act provisions.

124 See Nuncio D'Angelo "What directors need to consider before calling in an administrator - and it's not just solvency" (2006) 24 C\&SLJ 7 at 18.

125 Brown, above n 89 .

126 Companies Act, s 239AJ.

127 Section 239AN.

128 Kohere, above n 69.

129 Companies Act, s 245.

130 Harris, above n 38, at 118. 
role is to supervise the debtor-in-possession, and participate in the formulation of a plan for restructuring the company. ${ }^{131}$

There are, however, other costs accompanying the debtor-in-possession regime, including court supervision of the reorganisation plan. ${ }^{132}$ Any benefit of not appointing an external administrator may be off-set by other costs associated with the debtor-in-possession regime. Furthermore, allowing those responsible for the company's financial difficulty to manage its rehabilitation appears problematic. ${ }^{133}$ In reality, the debtor-in-possession regime requires engaging independent professional advisors, which ultimately leads to a position similar to appointing an administrator under New Zealand's current VA regime. ${ }^{134}$

\section{Addressing the stigma towards VA}

There appears to be a lack of confidence in VA, making it difficult for the regime to operate successfully. ${ }^{135}$ Changing the perception of VA is not something that can be done easily. However, if reforms were implemented that succeeded in aligning VA with its objectives, the regime may begin to operate as it was intended to. In turn, a change in creditors' perceptions of VA should follow. ${ }^{136}$

\section{Ipso facto clauses}

An area where the New Zealand VA regime departs from Australia is the status of ipso facto clauses. An ipso facto clause is a contractual provision allowing one party to terminate or modify the operation of the contract (or providing for this to occur automatically) upon the occurrence of a specified insolvency-related event. ${ }^{137}$ These clauses may allow important supply contracts to be terminated upon the appointment of an administrator. ${ }^{138}$

The termination of key supply contracts makes it difficult for a company in VA to trade out of insolvency. The Australian prohibition of ipso facto clauses was aimed at enhancing the likelihood that a company will be able to continue to trade in order to recover from an insolvency event. ${ }^{139}$ The

131 Bankruptcy, 11 USC $\S 1103$.

132 Harris, above n 38, at 119.

133 Australian Government Productivity Commission, above n 46, at 369.

134 At 369

135 At 367.

136 At 377 .

137 Paul Apáthy and others "Australia's New Ipso Facto Regime is now Live: Are Your Contractual Rights Affected?" (3 July 2018) Herbert Smith Freehills <www.herbertsmithfreehills.com>.

138 Rotherham, above n 69.

139 Apáthy and others, above n 137. 
New Zealand Insolvency Working Group's 2017 report did not recommend reforming ipso facto clauses. ${ }^{140}$ However, the ineffectiveness of VA as a rescue mechanism, reflected in the findings of the current research, may warrant further investigation and consideration of the status of ipso facto clauses in New Zealand.

\section{Further Points to Consider}

\section{The business debt hibernation scheme (COVID-19 response)}

The recently enacted COVID-19 Response (Further Management Measures) Legislation Act 2020 introduces a "Business Debt Hibernation" (BDH) process. This regime allows businesses impacted by COVID-19 to place their existing debts into "hibernation" until they are able to resume trading at normal levels. ${ }^{141}$ A key feature of the regime is an automatic one-month moratorium on the enforcement of debts from when a proposal is made to the company's creditors, with a further sixmonth moratorium available if 50 per cent of creditors (both in number and value) agree to the proposal. $^{142}$

In many respects, the $\mathrm{BDH}$ regime is similar to VA. The regime's objectives are to maximise the chances of the entity continuing to exist, and if this is not possible, it aims to provide a better return to creditors than what would have resulted from an immediate liquidation. ${ }^{143}$ The key difference (apart from the lack of an external administrator in the BDH regime) is that the BDH regime is targeted at viable companies that are facing financial difficulties because of the effects of COVID-19. ${ }^{144}$ VA, on the other hand, is relevant to companies who were facing difficulty (perhaps now more seriously) before COVID-19. ${ }^{145}$

It will be interesting to see the impact the BDH scheme will have on VA. The lower costs, lower threshold and longer automatic moratorium of the former make it an attractive option for companies in financial difficulty. ${ }^{146}$ That being said, VA offers far more flexibility in terms of what proposals can be made. Proposals under the BDH regime are limited to a six-month moratorium, whereas a wide

140 Insolvency Working Group, above n 112, at 40.

141 PricewaterhouseCoopers "COVID-19 Safe Harbours and Business Debt Hibernation: What will it mean for directors?" (17 April 2020) <www.pwc.co.nz>.

142 Companies Act, sch $13 \mathrm{cl} 15$.

143 Schedule $13 \mathrm{cl} 1$.

144 BWA Insolvency "Government's Business Debt Hibernation Scheme is a Watered-down Version of Voluntary Administration" (Press Release, 15 April 2020).

145 BWA Insolvency, above n 144.

146 Deloitte "COVID-19: Business rescue: Practical steps for a clear way ahead" (20 April 2020) <www2.deloitte.com/nz>. 
range of compromises can be proposed under a DOCA, which may be far more beneficial to creditors and company alike. ${ }^{147}$

\section{CONCLUSION}

VA has the potential to be an effective business rehabilitation tool if it is used as intended. VA has been chronically underused in comparison to other insolvency procedures, even when compared to Australia's almost identical regime. This may be attributable to the high costs to small businesses and general lack of confidence in the regime. VA does not appear to be performing as a successful corporate rescue mechanism with empirical evidence indicating that, for most companies, entering VA is a slippery slope to a removal from the companies register. While a plethora of reasons contribute to this result, the underlying issue seems to be the advanced stage that insolvency companies are in when they seek to use the regime.

Reform may take place through a number of avenues. However, it is clear there needs to be a shift in the way VA is perceived and used to set it on the right track. Once VA is moving in the right direction - that is to say achieving its objectives - companies and creditors alike may regain confidence in the regime. This will hopefully lead to an uptake in use, which may see VA becoming the viable option for companies in financial distress it was intended to be. ${ }^{148}$

147 Deloitte, above n 146.

148 (26 October 2006) 634 NZPD 6171. 